\title{
TANTANGAN MENCEGAH EIGENRICHTING DALAM BINGKAI KOMUNIKASI SOSIAL
}

\author{
Alen Manggola \\ UIN Sunan Kalijaga Yogyakarta \\ manggolaa@gmail.com
}

\begin{abstract}
ABSTRAK
Tujuan penelitian ini untuk melihat gambaran dari main hakim sendiri atau eigenrichting di dalam komunikasi sosial. Metode dalam penelitian ini menggunakan pendekatan kuantitatif, dengan metode penelitian explanatory research. Hasil Penelitian bahwa tindakan main hakim sendiri (Eigenrichting) ini kemudian dalam tatanan hukum nasional bertentangan dengan asas praduga tidak bersalah (presumption of innocence). Jadi seseorang tidak boleh dihukum bersalah atau tidaknya tanpa melalui suatu proses hukum, sebab ada kemungkinan seseorang tidak bersalah tetapi menjadi korban tindakan main hakim sendiri. Simpulan penelitian menunjukkan bahwa main hakim sendiri akan merespon situasi yang penuh ambisi tak terarah menjadi sikap yang memacu, bahwa sesuatu perlu pertimbangan yang matang sebelum bertindak, karena tak menutup kemungkinan akan mengakibatkan kerugian yang lebih besar.
\end{abstract}

Kata Kunci: Eigenrichting, Komunikasi Sosial.

\section{ABSTRACT}

The purpose of this study is to see the description of vigilante or eigenrichting in social communication. The method in this study uses a quantitative approach, with explanatory research methods. The results of the study that this act of vigilantism (Eigenrichting) is then in the national legal order contrary to the principle of presumption of innocence. So a person should not be convicted or not without going through a legal process, because there is a possibility that someone is innocent but becomes a victim of vigilantism. The conclusion of the research shows that vigilante will respond to situations that are full of undirected ambition into a spurring attitude, that something needs careful consideration before acting, because it does not rule out the possibility that it will result in greater losses.

Keywords: Eigenrichting, Social Communication. 


\section{PENDAHULUAN}

Tindakan eigenrichting atau main hakim sendiri merupakan tindakan melanggar hukum. Perlunya perhatian yang khusus akan tindakan melanggar hukum tersebut, sebab memberikan dampak yang sangat negatif bahkan menyebabkan hilangnya nyawa pada korban eigenrichting. Tidak hanya sekali hal demikian kita jumpai dalam kehidupan masyarakat, baik kejadian yang terdeteksi oleh pemberitaan media massa atau yang tidak terdeteksi. Tindakan penghilangan nyawa jauh lebih merugikan daripada kerugian harta benda. Sejalan dengan riwayat hadis bahwa, terbunuhnya manusia lebih berharga di sisi Allah daripada hilangnya dunia dan seisinya.

Tindakan eigenrichting menarik untuk menjadi pembahasan pada tulisan ini, sebagaimana keadaan fenomena terkait eigenrichting selalu ada setiap tahunnya. Pemberitaan sering kali mengabarkan terkait eigenrichting, sehingga hal tersebut adalah tantangan yang perlu diatasi dengan pencegahan yang sitematis bagi setiap akademisi dan setiap warga negara khususnya. Eigenrichting sangat cocok untuk di kaji dalam bingkai komunikasi sosial, sebab pentingnya peran komunikasi dalam setiap tindakan sosial khususnya masalah seperti eigenrichting yang menjadi perhatian bersama. Ketika mereka hanya sekedar terduga pelaku/pelanggar norma lingkungan masyarakat, dan harus mendapatkan siksaan sadis yang sangat memilukan bahkan merenggut nyawa mereka. Tidak hanya hukuman dunia bagi yang menyiksa, tapi juga dosa dan pertanggung jawaban dihadapan Allah. Maka, hal ini sangat penting untuk dikaji. Pencegahan bisa dilakukan apabila perilaku komunikasi sosial berjalan, dan berfungsi dalam bingkainya ketika setiap kali terjadi atau ada tertangkapnya para pelanggar norma lingkungan sehingga eigenrichting dapat dicegah. (Soerjono, 1990)

\section{METODE PENELITIAN}

Dalam penelitian ini, peneliti menggunakan metode kuantitatif. jenis pendekatan yang peneliti gunakan adalah jenis pendekatan analisis deskripsi kuantitatif dengan penelitian explanatory reasearch. Skala pengukuran yang digunakan yaitu skala likert.

\section{HASIL DAN PEMBAHASAN \\ Main Hakim Sendiri (Eigenrichting)}

Perbuatan main hakim sendiri berasal dari bahasa Belanda yaitu "Eigenrichting" yang berarti cara main hakim sendiri, mengambil hak tanpa mengindahkan hukum, tanpa sepengetahuan pemerintah dan tanpa penggunaan alat kekuasaan pemerintah. Perbuatan main hakim sendiri hampir selalu berjalan dengan pelanggaran hak-hak orang lain, dan oleh karena itu tidak diperbolehkan perbuatan ini menunjukkan bahwa adanya indikasi rendahnya kesadaran terhadap hukum. (Hamzah, 1986) Menurut Sudikno Mertokusumo, tindakan main hakim sendiri adalah tindakan untuk melaksanakan hak menurut kehendaknya sendiri yang bersifat sewenang-wenang, tanpa persetujuan dari pihak lain yang berkepentingan, sehingga akan menimbulkan kerugian. (Mertokusumo, 2010)

Dapat disimpulkan bahwa eigenrichting merupakan bentuk ketidak patuhan dan juga bentuk pelanggaran hukum. Perkembangan kehidupan masyarakat yang begitu cepat sebagai hasil dan proses pelaksanaan pembangunan di segala bidang kehidupan sosial, politik, ekonomi, keamanan, dan juga 
kebudayaan telah membawa pula dampak negatif berupa peningkatan kualitas dan kuantitas berbagai macam kejahatan yang sangat merugikan dan meresahkan masyarakat. Maka hal tersebut sudah jelas sebagai bentuk kesalahan yang terjadi di lingkungan masyarakat. Tentu mereka yang sadar akan eigenrichting merupakan bentuk kesalahan yang merugikan harus menjadi komunikator yang baik pada komunikan yang masih melakukan eigenrichting dilingkungan mereka. Perubahan akan mampu dilakukan dengan pola fungsi komunikasi sosial yang baik dalam bingkainya.

Sinergi antar tujuan yang mempengaruhi akan menciptakan sebuah sikap kesadaran, tentu yang sejalan dengan tujuan komunikasi sosial yang sedang dimainkan. Eigenrichting sama halnya dengan kerumunan yang berlawanan dengan norma-norma hukum (lawless c'rowds). Sejalan dengan Soerjono Soekanto menyatakan bahwa kerumunan yang berlawanan dengan norma salah satunya adalah kerumunan yang bertindak emosional (acting mobs). Kerumunan tersebut bertujuan untuk mencapai tujuan dengan menggunakan kekuatan fisik yang berlawanan dengan norma-norma hukum yang berlaku dalam masyarakat.

\section{Larangan Agama terhadap Eigenrichting}

Setiap permasalahan di muka bumi ini sudah diatur oleh penciptanya. Termasuk solusi sebagai petunjuk, larangan, dan juga hikmah yang perlu kita petik untuk bekal dalam setiap proses yang terjadi. Sebagaimana Islam juga mengatur akan hal kecil hingga hal yang perlunya perhatian khusus sebagaimana permasalahan yang terjadi di lingkungan sosial. Dalam hal itu Islam menjelaskan berdasarkan hukum, sehingga ada titik terang apakah dilarang atau diperbolehkan. Tentu semua dikemas sesuai dengan kebutuhan umatnya Rasulullah, guna untuk mempermudah agar dilaksanakan yaitu hukum Islam. Hukum Islam adalah sistem kaidah-kaidah yang didasarkan pada wahyu Allah SWT dan Sunnah Rasul mengenai tingkah laku mukallaf (orang yang sudah dapat dibebani kewajiban) yang diakui dan diyakini, yang mengikat bagi semua pemeluknya. Adapun pandangan agama pada eigenrichting, dalam Al-qur'an dikatakan bahwa:"Allah memerintahkan berbuat adil, mengerjakan amal kebaikan, bermurah hati kepada kerabat, dan Ia melarang melakukan perbuatan keji, munkar dan kekejaman. Ia mengajarkan kepadamu supaya menjadi pengertian bagimu. "(Q.S. An-Nahl [16]: 90)."Hai orang-orang beriman! Jadilah kamu penegak keadilan, sebagai saksisaksi karena Allah, dan janganlah kebencian orang kepadamu membuat kamu berlaku tidak adil. Berlakulah adil. Itu lebih dekat kepada takwa. Dan bertakwalah kepada Allah. Allah tahu benar apa yang kamu kerjakan."(Q.s. AlMaidah [5]: 8).

Dari Abu Hurairah beliau berkata: "Datang seseorang kepada Rasulullah kemudian dia berkata: "Wahai Rasulullah apa pendapatmu jika ada seseorang yang ingin merampas hartaku?" Nabi menjawab: "Engkau jangan memberikan hartamu kepadanya." Orang itu berkata lagi: "Bagaimana pendapatmu jika dia melawanku (karena aku tidak memberikan hartaku kepadanya)? Nabi menjawab: "Lawan dia!" Orang itu berkata: "Bagaimana pendapatmu jika dia membunuhku?" Nabi menjawab: "Engkau mati syahid." Orang itu berkata: "Bagaimana pendapatmu jika aku membunuhnya (karena melindungi harta dari perampasan)?" Nabi menjawab: "Dia di neraka." (HR. Muslim, riyadhus shalihin no. 1357). Berdasarkan hukum Islam melalui ayat dan hadis tersebut, bahwa 
larangan melakukan eigenrichtingdan dijelaskan juga bentuk solusi yang dianjurkan oleh hukum Islam. Sehingga hal tersebut akan mempermudah manusia dan umat Islam khususnya, dalam bersikap terhadap perilaku eigenrichting. Dengan adanya larangan agama akan membuat standar kejelasan hukum terhadap eigenrichting, maka yang perlu dilakukan adalah menjelaskan pada mereka yang belum mengetahuinya sejalan dengan konsep komunikasi sosial sehingga mampu mencapai tujuan yang diharapkan.

\section{Komunikasi Sosial}

Aspek dalam komunikasi memiliki fungsi yaitu fungsi sosial. Menurut Rudolph F. Verderber komunikasi sosial merupakan komunikasi yang dengan tujuan untuk menunjukkan ikatan dengan orang lain, membangun dan memelihara hubungan. (Hamid, 2011). Adapun menurut Thomas M. Scheidel komunikasi sosial untuk membangun kontak sosial dengan orang lain di sekitar kita dan untuk mempengaruhi orang lain untuk merasa, berpikir, atau berperilaku seperti yang kita inginkan. Dan tujuan terpentinya adalah untuk mengendalikan lingkungan fisik dan fsikologis seseorang. (Hamid, 2011). Komunikasi sosial mencirikan hubungan sosial dan proses aktifitasnya di lingkungan masyarakat. Sehingga apa yang menjadi isu sosial termasuk eigenrichting akan mencuri perhatian komunikasi. Seperti kesadaran diri, eksistensi diri, pengetahuan dan memupuk hubungan merupakan bentuk terpenting dalam bingkai komunikasi sosial.

\section{Kesadaran Diri}

Tidak setiap orang sadar akan dirinya selama ia menutup diri dari lingkungan, dan sehingga tidak mengetahui apa yang terjadi di sekitar tempat ia berada. Bagaimana ia akan memahami dirinya jika lingkungan tidak memberi pengakuan ataupun nilai pada dirinya. Seseorang tidak akan memahami bagaimana cara mengatasi permasalahan, ketika ia mau tak mau harus berinteraksi pada lingkungan sedangkan ia tidak mengetahui cara yang sesuai dengan harapan norma lingkungan yang berlaku. Seringkali para pelaku eigenrichting merupakan mereka yang tidak mengenal dirinya apalagi mengenal orang lain. Maka sifat ikutikutan dan sikap yang brutal akan ia lampiaskan terhadap mereka yang dianggap melanggar ataupun benar-benar melanggar hukum lingkungan. Tentu mereka akan menyamaratakan akibat dan tidak melihat seberapa besar nilai kerugian yang diakibatkan oleh korban eigenrichting. Perlunya komunikasi sosial yang dimainkan dalam pembentukan kesadaran diri seseorang. Seseorang harus bisa menyatu dengan lingkungan sehingga tau betul seberapa besar masalah, dan bagaimana solusi positifnya, serta tentu hal tersebut sejalan dengan norma yang berlaku. Seseorang yang paham akan dirinya akan sejalan dengan hadis "cintailah orang lain sebagaimana kamu mencintai diri kamu sendiri”.

Maka, apabila hal tersebut ditanamkan dalam menghadapi setiap para pelanggar norma tentu ia akan lebih bijaksana dan terarah responsifnya untuk solusi agar tidak timbul korban lagi. Kita harus memahami jika itu terjadi pada kita ataupun keluarga kita. Sedangkan kita semena-mena terhadap orang yang tentu perlu kita lindungi haknya dan percayakan pada penegak hukum akan hukuman yang cocok untuk kadar pelanggaran yang dilakukan. George Herbert Mead mengatakan setip manusia mengembangkan konsep dirinya melalui interaksi dengan orang lain dalam masyarakat dan itu dilakukan melalui 
komunikasi. Jadi seseorang mengenal dirinya melalui orang lain, yang menjadi cermin yang memantulkan bayangan kita. Mulyana (2005) dan Charles H. Cooley menyebut konsep diri itu sebagai the looking glass-self, yang secara signifikan ditentukan oleh apa yang seseorang pikirkan mengenai pikiran orang lain terhadap dirinya. Jadi, menekankan pentingnya respons orang lain yang diinterpretasikan secara subjektif sebagai sumber primer data mengenai dirinya. Sehingga kesimpulannya adalah kesadaran diri terhadap apa yang akan kita lakukan pada orang lain akan lebih memahami jika itu adalah diri kita.

\section{Eksistensi Diri}

Akademisi komunikasi sangat memahami eksistensi diri, sebab orang berkomunikasi untuk menunjukkan bahwa dirinya eksis. Sebagaimana frase filosof Prancis Rene Descartes dari "saya berpikir, maka saya ada" menjadi "saya berbicara maka saya ada". Hal tersebut menjelaskan bahwa ketika seseorang hanya diam saja maka orang lain akan memperlakukan kita seolah-olah kita tidak eksis. Membangun eksistensi diri sangat bersinggungan dengan komunikasi sosial. Setiap kehidupan sosial membutuhkan sikap eksis agar terlihat dan diakui oleh sosial dimana ia berada. Terlebih itu adalah seseorang yang memiliki kewenangan yang lebih daripada mereka yang berada di suatu lingkungan tersebut. Eksistensi diri juga tak lepas dari konsep diri bagaimana ia dengan lingkungannya. Sebab semua akan mempengaruhi pengetahuan dan interaksi dirinya dengan orang lain dan masalah sosial lingkungannya.

Setiap mereka yang memiliki kekuasaan juga perlunya sikap yang bijaksana. Tidak sedikit yang masih melakukan tindak eigenrichting padahal ia adalah sebagai pengarah kebijakan yang ada di lingkungannya. Bahkan ia menjadi yang paling brutal melakukan kekerasan, tentu semua itu perlunya perhatian yang mesti dipikirkan oleh setiap anggota masyarakat. Banyak bentuk sikap untuk mengekspos diri dalam lingkungan masyarakat, dan semua bertujuan agar dikenal dan disegani ucapan dan perbuatan yang dilakukan. Hal itu akan sangat bepengaruh terhadap respon kepercayaan orang lain terhadap dirinya. Dan sangat mudah untuk menyuntik mereka yang sebenarnya butuh solusi. Sebab kadang mereka melakukan karena mereka tidak memiliki cara yang lebih baik, dan kesadaran yang maksimal dalam menangani masalah yang dihadapi, termasuk ketika adanya pelanggaran sosial yang bisa berakibat pada eigenrichting.

\section{Pengetahuan}

Pentingnya pengetahuan akan hukum yang berlaku, agar hukum itu juga tidak memfonis mereka yang menghakimi atas sikap semena-mena yang dilakukan. Mengamati banyaknya kejadian main hakim sendiri yang dijadikan sebagai jalan dalam menyikapi berbagai tindak kejahatan di tengah masyarakat saat ini, sehingga perlu pemahaman hukum dari beberapa kajian penting untuk menyadarkan dan memberi pengetahuan bagaimana kajian ini perlu dibahas.

Permasalahan main hakim sendiri sudah sejak lama menjadi persoalan yang tak kunjung usai dan sering terjadi di dalam hukum Indonesia, sesuai dalam Pasal 1 ayat (3) Undang-undang Dasar Negara Republik Indonesia disebutkan bahwa "Negara Indonesia adalah negara hukum," sudah seharusnya praktik main hakim sendiri di Indonesia harus mendapat tindakan tegas karena realitanya hal tersebut masih sering ditemui di negara yang berdasarkan atas hukum ini. 
Pengetahuan sangat menentukan pola sikap seseorang, dan kepercayaan diri juga akan semakin yakin untuk menentukan sikap.

Dalam hal ini pengetahuan akan apa yang harus dilakukan, apa akibat yang akan terjadi, dan tentu pertimbangan yang positif (sikap bijaksana) merupakan jalan yang akan ditempuh oleh mereka yang memiliki pengetahuan. Sejalan dengan luasnya pengetahuan serta pengalaman sebagai pengetahuan akan menuntun perilaku, dan juga strategi khusus dalam mengatasi permasalahan. Sehingga otot tidak mengambil peran dalam hal ini apabila pengetahuan mampu merespon mereka yang eigenrichting. Ketika pengetahuan akan cara mengatasi benih-benih eigenrichting sudah diketahui, maka tindakan akan mampu menghalau bisa dilakukan dan akan berbuah manis ketika pesan mengenai mereka, dalam bentuk solusi tanpa harus menimbulkan kerugian yang lebih besar, dari sekedar pelanggaran norma oleh korban eigenrichting.

\section{Memupuk Hubungan}

Sikap saling sinergi dalam anggota lingkungan sangat memberikan dampak positif untuk setiap permasalahan yang ada dan akan ada di suatu lingkungan sosial. Ketika struktur anggota masyarakat sudah jelas maka masingmasing memiliki tanggung jawab dan sikap hormat terhadap petinggi lingkungan untuk urusan lingkungan yang mereka tempati. Selain itu, sikap saling peduli terkait urusan lingkungan ataupun pribadi akan memberikan gambaran yang positif untuk bisa bekerja sama membangun lingkungan.

Perlunya komunikasi dalam setiap aktivitas yang memungkinkan untuk saling mengenal dan tolong menolong akan membuat masing-masing saling menghargai satu sama lain. Memupuk hubungan pada anggota masyarakat sekitar kita merupakan bentuk menanamkan eksistensi diri. Semua mudah untuk dikendalikan dengan pola komunikasi singkat sehingga tidak butuh waktu yang lama untuk memberikan keyakinan bahwa yang disampaikan akan berdampak positif untuk lingkungan. Ketika terjadi hal yang mengancam dan butuh perhatian khusus mereka akan saling mengerti dan menghargai dalam hal keputusan yang positif, tentu ini menjelaskan bahwa memupuk hubungan sangat menentukan pencegahan eigenrichting.

\section{Tantangan Mencegah Eigenrichting \\ Nafsu Menghakimi Berlebihan}

Agresi terbagi menjadi dua yaitu agresi positif dan agresi negatif. Agresi positif merupakan tindakan agresi yang dapat dibenarkan sebagai akibat dari pembelaan seseorang terhadap ancaman atau serangan. Sedangkan agresi negatif adalah serangan atau perbuatan dilakukan secara sengaja terhadap orang lain dengan tujuan untuk melukai orang yang diserang. (Adryanto, 1985) Ketika terjadi luapan emosi massa tentu masing-masing bersikap yang sama yaitu ingin menghakimi dan memusnahkan pelaku kejahatan. Sepakat semua menyatakan ia bersalah dan harus kita hukum. Padahal tak ada hak mereka untuk menghukum terlebih meluncurkan pukulan ataupun siksaan meski tujuannya untuk memberi efek jerah.

Sejalan dengan pendapat Psikolog Sulut Orley Charity Sualang mengatakan perilaku main hakim sendiri identik dengan agresi dan psikologi massa. Agresi adalah perasaan marah meluap-luap yang melibatkan pengiriman 
stimulus berbahaya dan diwujudkan dengan respon perilaku sengaja, seperti melukai atau mencelakakan orang lain, melanggar hak orang secara paksa, penyerangan, penghinaan dan frustasi. Sedangkan penyebab agresi yaitu; faktor situasi dan faktor pribadi. Perilaku agresi akan semakin besar ketika dilakukan secara berkelompok (massa). Hal tersebut bisa terjadi karena agresivitas aktif orang-orang dalam kelompok, akan mampu menjadi pendorong munculnya agresivitas orang yang sebelumnya pasif. Tentu peran seseorang yang mengingkari eigenrichting adalah meredam emosi tersebut dan mencegah perbuatan brutal massa. Semua akan dapat dilakukan apabila menguasai aspek komunikasi sosial dalam tujuannya. Sebab, perbuatan eigenrichting itu sangat berbahaya dan bahkan sampai pada hilangnya nyawa jika nafsu menghakiminya terlalu berlebihan. Walaupun semua sepakat korban adalah salah dan harus dihukum agar tidak mengulangi dan juga sebagai peringatan bagi pelanggar lainnya yang dikemudian hari bisa saja melakukan kesalahan atau pelanggaran di dalam lingkungan.

\section{Memilih Ikut-ikutan dan Diam}

Massa pasif yang semula ragu-ragu atau khawatir akan berbalik keyakinan untuk berani ikut dalam eigenrichting. Hal itulah yang kemudian akan memicu faktor ikut-ikutan dalam eigenrichting yang dilakukan oleh beberapa orang. (Walgito, 2002) Menurut Athalia Sunaryo psikolog dari Lifespring Counseling dan Care Center, perilaku masyarakat yang tega bertindak main hakim sendiri tidak terlepas dari pengaruh adanya kondisi psikologis yang berbeda saat seseorang berada di dalam kelompok tertentu, sehingga cenderung melakukan halhal yang berbeda dengan nilai pribadi yang dimilikinya.

Sejalan dengan beberapa penjelasan berikut ini: 1) Konformitas sosial yaitu proses dimana tingkah laku seseorang dipengaruhi atau terpengaruh oleh orang lain di dalam suatu kelompok yang terdiri dari orang saling atau tidak saling mengenal. Hal demikianlah yang sering terjadi dalam situasi main hakim sendiri. Sebab, dari orang yang saling atau tidak saling mengenal berkumpul dan memiliki kesamaan pandangan dengan menganggap bahwa orang yang melakukan kejahatan harus dan pantas dihukum. Kemudian tanpa pikir panjang karena melihat situasi orang lain juga berbuat demikian, maka mereka mengikuti tindakan main hakim sendiri dengan berbagai bentuk penyiksaan. Seolah jika orang dalam kelompok berbuat demikian, berarti itu merupakan tindakan yang benar, padahal itu salah. 2) Bystander effect merupakan suatu keadaan dimana seorang individu tidak akan melakukan tindakan apapun untuk menolong, sekalipun ada situasi kritis jika ada orang lain yang hadir di sana.

Dalam situasi ini main hakim sendiri, biasanya tidak semua orang yang berkerumun melakukan tindakan penyerangan, pemukulan, ataupun tindakan lain yang bisa disebut hanya menjadi penonton saja. Karena ada rasa takut menerima dampak negatif (misal ikut mengalami penyerangan) jika bertindak juga dapat menghalangi seseorang untuk melakukan hal yang dianggapnya benar. Memilih untuk diam merupakan sikap komunikasi bahwa ia membiarkan hal negatif terjadi sedangkan ia melihat hal tersebut dan sebenarnya juga mampu apabila ia bertindak dengan bijaksana. Apalagi ketika seseorang malah ikut-ikutan tanpa peduli apa yang sebenarnya terjadi. Maka hal tersebut perlunya sikap yang mampu menghalau setiap aksi yang akan menimbulkan atau memancing sikap 
eigenrichting. Kedua sikap tersebut merupakan tantangan yang akan dihadapi seseorang yang akan menghalau eigenrichting, sehingga perlunya sikap yang tidak hanya sekedar ikut-ikutan atau membiarkan terjadinya eigenrichting. Sikap yang bijaksana akan mengontrol diri dan segera mencari solusi terbaik agar tidak timbul korban pada kedua belah pihak yang akan bersikap eigenrichting.

\section{Lemah Pengetahuan}

Dilihat dari sisi hukum para pelaku tindak pidana main hakim sendiri yang biasanya melakukan tindakan berupa penganiayaan, perusakan, perampasan bahkan pembunuhan baik yang dilakukan secara bersama-sama maupun sendiri dapat dikenai ketentuan Pasal 351 KUHP tentang penganiayaan, Pasar 406 KUHP tentang menghancurkan atau merusak barang, Pasal 338 KUHP tentang kejahatan terhadap nyawa, salah satunya Pasal 170 ayat (1) dan (2) Kitab Undang-undang Hukum Pidana yang bunyi pasalnya sebagai berikut: 1). Barang siapa dengan terang-terangan dan dengan tenaga bersama menggunakan kekerasan terhadap orang atau barang, diancam dengan pidana penjara paling lama lima tahun enam bulan. 2). Yang bersalah diancam: a). Dengan pidana penjara paling lama tujuh tahun, jika ia dengan sengaja menghancurkan barang atau jika kekerasan yang digunakan mengakibatkan luka-luka; b). Dengan pidana penjara paling lama sembilan tahun, jika kekerasan mengakibatkan luka berat; c). Dengan pidana penjara paling lama dua belas tahun, jika kekerasan mengakibatkan maut.

Bentuk hukum sudah sangat jelas memberikan peringatan yang keras bagi mereka yang melakukan eigenrichting. Namun tentu hal tersebut juga perlu diketahui semua anggota masyarakat melalui forum berbagai aktivitas bersifat massa. Selain itu pengetahuan dalam mengambil sikap juga sangat perlu diketahui oleh mereka yang parkir pengetahuan. Sehingga solusi dalam saling bertukar pengalaman dari pengetahuan yang diperoleh yang tentu berbeda-beda, dan untuk diambil sisi positifnya juga menjadi hal yang urgen. Seseorang akan tersesat saat ia dalam keadaan bodoh tak berilmu tentang apa yang sedang dihadapinya. Sehingga perlu arahan yang secara sistematis untuk mempermudah keefektifan komunikasi yang akan diluncurkan kepada kekosongan pengetahuan tersebut. Perbuatan eigenrichting selalu sejajar dengan pelanggaran hak-hak orang lain, maka tidak diperbolehkannya perbuatan tersebut menunjukkan bahwa ada indikasi rendahnya terhadap kesadaran hukum. (Hamzah, 1996)

\section{Lingkungan yang Pasif}

Komunikasi terhadap orang lain mestinya tetap kita pupuk terlebih lagi pada mereka yang berada di sekitar kita. Sehingga kita dapat mengetahui setiap apa saja yang terjadi di lingkungan kita. Kebutuhan seseorang akan hubungan terhadap anggota individu di lingkungan tersebut sangat menentukan betapa bernilainya diri seseorang akan diperhatikan oleh anggota sekitar atau dimana ia berada. Maka eksistensi seseorang akan menjadi pertimbangan untuk mencegah apa saja yang akan mengancam di lingkungannya. Akan tetapi kebanyakan dari daerah-daerah yang sering terjadi eigenrichting dikarenakan lingkungan yang pasif.

Anggota masyarakat di dalam lingkungan tersebut selain berbeda tingkatan sosial kadang juga tidak memupuk komunikasi yang membuat lingkungan terlihat aktif. Hal tersebut terlihat dari berapa banyak aktivitas atau 
agenda mereka untuk bersama dan saling berkomunikasi antar satu dengan yang lainnya. Seperti beberapa lingkungan mengadakan kegiatan positif dari hal yang terkecil hingga hal yang lebih serius terkait keamanan lingkungan mereka. Maka dalam hal ini yang terpenting adalah membuat lingkungan tetap aktif dan memiliki solusi yang positif terhadap apapun terkait lingkungan mereka termasuk eigenrichting.

\section{SIMPULAN}

Dalam prosesnya komunikasi akan mengacu pada setiap permasalahan yang sedang terjadi, dan yang akan terjadi di setiap aspek termasuk aspek sosial. Hingga menghasilkan pandangan yang positif, pada setiap masalah yang muncul dalam penyelesaiannya. Sehingga proses yang mampu mengkreasikan sebuah pandangan, dan kesempatan untuk mengubah keadaan dari yang bersifat pasif menuju aktif dalam bingkai komunikasi. Pandangan itu akan merespon situasi yang penuh ambisi tak terarah menjadi sikap yang memacu, bahwa sesuatu perlu pertimbangan yang matang sebelum bertindak, karena tak menutup kemungkinan akan mengakibatkan kerugian yang lebih besar. Sehingga proses itu memberikan gambaran, bahwa banyak kemungkinan tanpa kesadaran diri. Namun sikap kesadaran diri perlu dorongan yang mendukung maksimal dalam prosesnya yaitu dengan adanya eksistensi diri. Seseorang mungkin punya kesadaran penuh akan hal yang sedang terjadi untuk menghalaunya agar tidak terjadi hal yang tidak diinginkan, akan tetapi ia tidak memiliki power perhatian yang maksimal.

Maka hal itu tentu akan menjadi penerang bagi sikap bijaksana untuk bertindak, dan adanya dukungan penuh dari individu lainnya, yaitu pengaruh eksistensi dirinya terhadap posisi ia di lingkungan tersebut. Kekuatan akan maksimal apabila yang disampaikan adalah pesan yang memiliki nilai yang mampu memukau mereka yang akan bertindak anarkis. Tentu hal tersebut perlunya pengetahuan yang cukup untuk menjelaskan kepada mereka bahwa itu salah dan ini benar. Maka dalam hal pengetahuan, eksistensi diri dan kesadaran diri tersebut akan komplit ketika adanya upaya yang tanpa lelah untuk memupuk hubungan dengan masing-masing anggota lingkungan masyarakat. Terlebih proses tersebut akan berlangsung dalam waktu yang tak terbatas. Sebagaimana tindakan eigenrichting selalu memicu perhatian sejalan dengan tindakan kriminalitas yang kerap terjadi di lingkungan masyarakat pada umumnya.

\section{DAFTAR PUSTAKA}

Adryanto, M. (1985). Sosial Psychology. Jakarta: Erlangga. Hlm 03

Hamid, F. (2011). Ilmu Komunikasi Sekarang dan Tantangan Masa Depan, Jakarta: Kencana. Hlm. 25.

Hamzah, A. (1986). Kamus Hukum. Jakarta: Ghalia Indonesia. Hlm. 167

Mertokusumo, S. (2010). Hukum Acara Pidana Indonesia. Yogyakarta: Liberty. Hal. 03

Muladi, M. (1997). Hak Asasi Manusia dan Sistem Peradilan Pidana. Semarang: Badan Penerbit Universitas Diponegoro.

Mulyana, D. (2005). Ilmu Komunikasi Suatu Pengantar. Bandung: PT. Remaja Rosdakarya. Hlm. 06.

Soekanto, S. (1990). Sosiologi sebagai Pengantar. Jakarta: PT. Raja Grapindi Persada. Hlm.161 
Soekanto, S. (1996). Kejahatan dan Penegakan Hukum di Indonesia. Jakarta: PT. Rineka Cipta.

Supianto, E. (2014). Skripsi: Tinjauan Kriminologis terhadap Tindakan Main Hakim Sendiri yang dilakukan oleh Massa terhadap Pelaku tindak Pidana. Makasar: Universitas Hasanuddin Makasar. http://repository.untad.ac.id/1898/

Walgito, B. (2002). Psikologi Sosial (Suatu Pengantar). Yogyakarta: Andi Offset. 102-103. 